\title{
Skills to Look At The Facts Based on Audio Visual Media to Improve Fine Motor Skills in Grahita Tuna Children in SLB Cendono
}

\author{
Wahyu Riswanto ${ }^{1}$, A. Hilal Madjdi², Su' $^{3}{ }^{3}$ \\ \{Wahyu_riswanto123@yahoo.com ${ }^{1}$ \} \\ 1,2,3 Universitas Muria Kudus, Indonesia
}

\begin{abstract}
The purpose of this study was to determine the skill of listening to fairy tales based on audio-visual media to improve fine motor skills in mentally disabled children in SLB Cendono. The study uses a qualitative approach with qualitative descriptive techniques. This study aims to find the right method in teaching fairytale based audio visual media teaching skills, especially in fourth grade students of SLB Negeri Cendono. Class action research is intended so that teachers and researchers know the weaknesses in teaching Indonesian especially vocabulary teaching, which later the results of this research are expected to be useful for teachers, researchers and students in the teachinglearning process.Classroom action research will involve things like the following: planning, acting, observing and reflecting. This class action research will be conducted in three cycles. In each cycle there are 4 steps: planning, acting, observing, reflecting. The study population was students of Class I-VI. SLB Negeri Cendono with 115 students consisting of 6 classes. teachers and researchers will discuss how to use appropriate methods for effective and efficient teaching. Students will be respondents for testing the vocabulary teaching method through storytelling short stories. Data collection techniques and instruments are observation in the form of a checklist, to observe all aspects that occur in class learning. The test is an objective test that will be tested on students. The last instrument is interviews that will be conducted on teachers and students by using semistructured interview guidelines. The data of this study were collected through observation, tests and interviews to be analyzed using a percentage of the mean score to find deficiencies in the application of a teaching method. The data obtained will be analyzed descriptively quantitatively.This research is expected to increase the vocabulary mastery of SLB Cendono students. through understanding short stories with efficient and effective teaching for the creation of harmonious and fun classes by using cycle actions that will be applied in teaching Indonesian, especially vocabulary teaching.
\end{abstract}

Keywords: Audio Visual Media Based Storytelling Skil

\section{PRELIMINARY}

The 2013 curriculum is the curriculum that currently applies in the education system in Indonesia. This curriculum is a curriculum implemented by the government replacing the 2006 curriculum called the Education Unit Level Curriculum (KTSP). The 2013 curriculum began to be 
tested in 2013 by turning several schools into pilot schools. Curriculum 2013 began to be implemented in pilot schools (pilot project) in the 2013/2014 school year, namely in classes I and IV for elementary school (SD), class VII for junior high school (SMP), and class X for secondary school level Upper (high school) / Vocational High School (SMK).

The implementation of the 2013 Curriculum was stopped and for a while schools returned to using the 2006 Curriculum or Education Unit Level Curriculum (KTSP) except for schools that had implemented it for 3 (three) semesters. This is based on the Minister of Education and Culture Regulation No. 60 of 2014 on December 11, 2014 by the then minister, Anies Baswedan. The termination is intended to revise the curriculum.

The implementation of the 2013 Curriculum was stopped and for a while schools returned to using the 2006 Curriculum or Education Unit Level Curriculum (KTSP) except for schools that had implemented it for 3 (three) semesters. This is based on the Minister of Education and Culture Regulation No. 60 of 2014 on December 11, 2014 by the then minister, Anies Baswedan. The termination is intended to revise the curriculum.

After undergoing a revision, finally in the 2016/2017 academic year 2013 Curriculum was implemented nationally, although in reality there were still schools that had not fully implemented the 2013 Curriculum, for example only only classes I, IV and VI were implementing the 2013 Curriculum. The rest were using the Education Unit Level Curriculum ( KTSP). The stages of implementing Curriculum 2103 in accordance with the agreement of the Ministry of Education and Culture and the House of Representatives (DPR) are carried out in stages (Kemendikbud, 2016). Tjipto Sumadi who is the Head of the Ministry of Education and Culture's Curriculum and Book Center (Puskurbuk) in an educational dialogue that discussed the implementation of the 2013 Curriculum at the Grand Inna Hotel Kuta Bali on June 11, 2016 said "Previously the school that implemented the 2013 Curriculum was $6 \%$, then now it adds $19 \%$ to $25 \%$. Later we increase it again by $35 \%$ to $60 \%$. So that in the $2018 / 2019$ school year the implementation is targeted to have reached $100 \% "$. Some of the things that were revised were, among others, no longer a double assessment. Previously, every subject teacher was obliged to make a judgment from the spiritual aspect, not kinti anymore. Spiritual assessments are submitted to the subject teachers of Religion and PPKn (Pancasila Education and Citizenship). This change in dual assessment will reduce the burden on teachers who were previously complained by many teachers.

The first key in directing the education and learning of students in an education is located in an educator. Educators will succeed in developing their learning if they know students through their own children, especially in the environment, and family.

The role of the teacher is to develop and maintain rules or discipline in the classroom. Children need optimal motor development, and this requires the role of the teacher in motor development in the educational environment where the child is nurtured and cared for. The involvement of parents and teachers strongly supports the optimization of the child's motor development.

Education is a business or activity that is carried out intentionally, regularly and planned with the intention of changing or developing the desired behavior. School as a formal institution is a means in order to achieve the educational goals. Through school, students learn a variety of things that indicate a positive change so that at the final stage will be able to get new skills, abilities, and knowledge. Education is inseparable from the learning process which is the core activity in formal education in schools. In learning there is a process of interaction between the teacher component, subject matter, and students. Interaction between these components involves facilities and 
infrastructure such as methods, media, and structuring the learning environment, so as to create a learning situation that allows the achievement of the goals that have been planned before (Ali, 2007: 4).

Of the several components of learning, teachers and students are the most vital components that influence in learning. In the learning process, teachers and students greatly influence the success of learning. Sardiman (2010: 146) argues that the teacher's relationship with students / students in the learning process is a very determining factor. However good the subject matter or teaching material provided, however perfect the method used, but if the relationship between teacher and student is not harmonious then it can create undesirable results.

In children's learning special education is different in children generally without always showing mental, emotional or physical disabilities. Other children with special needs include: visually impaired, deaf, mentally retarded, mentally retarded, learning difficulties, children with health problems. Other terms for children with special needs are exceptional children and children with disabilities.

With the paradigm shift in education that is towards inclusive education, students who experience motor impairments, especially in children with special intellectual disabilities must have special handling in learning in schools that is more basic in children with special needs training fine motor skills in everyday life, because it is very important and needs to be trained first life skills are life skills to be useful for the community and have a decent inner life. Both of these life skills help mentally disabled children in growing their self-confidence to face the changes that occur in themselves and their environment in order to be independent.

Based on the pre-research above the process of developing fine motor skills in SLB Tunagrahita is still underdeveloped due to the lack of learning media and enthusiasm in activities. In addition to the author doing observations in the classroom when the teacher is in motor development activities of the child the author also conducted an interview with the headmaster of Cendono State SLB, from the results of the interview the writer obtained information about his SLB not implementing the process of developing fine motor skills. Interview Results of SLB School Principals According to SLB principals and teachers in the learning process have implemented the process of developing fine motor skills. However, there are not many media used, so children easily feel bored. This is caused by the lack of facilities and infrastructure at school and the knowledge of education staff about ways to develop fine motor skills in SLB. To that end, the author decided to conduct a study with the title: Tune-in Skill of Audio-Based Media Tales to Improve Fine Motor Ability in Children with Physical Disabilities.

\section{METHOD}

This research is a descriptive study of the analysis of the learning process at the Elementary Extraordinary School (SDLB) section C (tuna grahita) at the Cendono State Extraordinary School (SLB), so the approach used in this study is qualitative. This research uses a qualitative research approach. Moleong (2013: 6) defines that qualitative research is research that intends to understand phenomena about what is experienced by research subjects, for example behavior, perception, motivation, actions, etc. holistically and by means of descriptions in the form of words and language, in a special natural context and by utilizing various natural methods. Furthermore According to Moleong (2013: 8-13) qualitative research has characteristics: (1) has a natural 
setting; (2) researchers as the main instrument; (3) using qualitative methods; (4) inductive data analysis; (5) theory from the ground (grounded theory); (6) descriptive; (7) prioritizes the process over the results; (8) there are limits determined by the focus of the study; (9) there are criteria for the validity of the data; (10) the research design is temporary; and (11) the results of the study are negotiated and agreed upon together.

According to Creswell (2016: 4), qualitative research is methods to explore and understand the meaning by a number of individuals or groups of people ascribed to social or humanitarian problems. Qualitative research is often referred to as a naturalistic research method because the research is carried out in natural conditions. Researchers used various sources of information in gathering data to provide a detailed and in-depth picture of the Analysis of the Learning Process in C Elementary Extraordinary Schools (SDLB) in Cendono State Special Schools (SLB).

\section{RESEARCH RESULT}

The last process in teaching is conducting an evaluation. From the evaluation carried out this is a teacher can find out the level of achievement of learning objectives that have been formulated. Conducting evaluation of learning requires a clear assessment of reference. In learning an assessment as an activity to know the development, progress or student learning outcomes.

From observations and interviews conducted there are problems experienced by teachers when they have to do an assessment. The teacher evaluates the students 'independence by conducting students' fine motor skills. However, teachers have difficulty when giving scores to students. The teacher seems hesitant to give grades to students. But that is exactly what happens during the learning process. This is due to the different abilities of students.

Even though the results of the assessment given by the teacher are a description of the evaluation that will be carried out. Evaluation is intended to find out not only the achievement of learning objectives but through evaluation activities it will be known how the learning process has been carried out, starting from the learning objectives that have been formulated, the material chosen, the media used and also how the methods to harmonize all of it.

As stated by Kelvin (2010: 8) evaluation is the overall assessment of education. Assessment is done by taking measurements. This measurement activity will have meaning after it is linked to the purpose of assessing students' abilities. So Baxter in Kelvin (2010:9) stated the importance of assessment in learning are:

1. To compare abilities between students with other students

2. To find out the results that have been achieved by students have met the specified standards

3. To help student learning activities

4. To find out whether the learning has been carried out in accordance with what was planned.

From the results of research conducted, the problem faced by teachers is actually only the lack of knowledge of teachers about learning that has not been effective, and the lack of media so that researchers help provide solutions so that interesting learning media are held for students and it is easy to practice fine motor skills in mentally retarded children. become active and participate in learning to the maximum even though there is one student who does not participate at least reduces the laziness of students in carrying out daily learning. With the existence of audio-visual media-based learning media listening to fairy tales to train students fine motor skills applied in 
mentally retarded children. Another obstacle is that teachers cannot use audio media, and researchers provide training so that teachers can use audio visual based media.

According to Panggabean et al (2007: 111) an evaluation must be carried out as well as possible so as not to produce the wrong decision. Moreover, the mistakes made can harm students. Therefore there are several conditions that must be considered in conducting an evaluation, namely:

\section{Valid (Valid)}

A valid evaluation is an evaluation that measures what should be measured

\section{Reliable}

Evaluation is said to be reliable if it has been tested with the same group at different times and got the same results.

\section{Objectivity}

An evaluation must be carried out as objectively as possible so that the results of the assessment are not influenced by things beyond what will be measured.

\section{Balance}

Balance means the right weight in each part of the assessment.

\section{Can discriminate}

Proper evaluation must be able to discriminate between individual achievements with groups.

6. Fair

A good evaluation is an evaluation that raises a problem clearly, naturally and not trapping

\section{Normative}

A good evaluation is based on certain norms so that the results are easily interpreted thoroughly and evenly without favoritism.

\section{Efficiency and Practical}

Evaluations must be carried out easily and efficiently, the implementation of which is not too complicated. Evaluations must be carried out in a practical way rather than confusing.

The problem that is found by teachers when teaching is that the media used by the teacher is not suitable to be applied for mentally retarded students because the teacher uses the general curriculum to teach inclusive students. The teacher does not pay attention to the needs of mentally disabled students to learn.

\section{CONCLUSION}

Based on the results of the analysis that the author has seen, it can be concluded that the teacher has not used an educational game that attracts children to enthusiasm in carrying out 
activities in the process of developing fine motor skills in SLB Negeri Cendono beginning with the teacher preparing materials for children's activities, then the teacher explains in advance the activities like what the child will do. After explaining the teacher shares the activities that the child will create and the child begins to do his work. Based on the research the authors conclude that the process of developing fine motor skills in SLB Negeri Cendono has not yet developed to the fullest this is evident from 115 children, 60 children (10\%) have not developed, 30 children (75\%) have begun to develop, 25 children $(15 \%)$ developed as expected, 0 children $(0 \%)$ developed very well. The researcher concludes that the teacher's explanation is less than optimal and the educational game tools are less varied.

\section{BIBLIOGRAPHY}

Junal:

Ali, Mohamad. 2007. Science and Educational Applications Part I: Theoretical Education. Bandung: PT IMTIMA

Bafadal, Ibrahim. 2005. Improvement of Primary School Teacher Professionalism. Jakarta: PT Bumi Aksara

Bogdan, R. C. and Biklen. 1992. Qualitative Research for Education: An Introduction to Theory and Methods. Boston: Allyn and Bacon.

Creswell, W. John. (2016). Research Design: Qualitative Approach, Quantitative and Mixed Approaches. Yogyakarta: Student Library

Eko Putro., W. 2012. Techniques for Forming Research Instruments. Yogyakarta: Student Library 